\title{
The Ability of Water Hyacinth, Heartshape False Pickerelweedand Water Lettuce as Chlorine Phitoremediation in Water
}

\author{
Hariyadi \\ Department of Biology, Faculty of Mathematic and Natural Science, University of Christiany Tomohon, Indonesia \\ Corresponding author email: hariyadikilis@gmail.com
}

\begin{abstract}
This study aims to determine the ability of water hyacinth, heartshape false pickerelweed, and water lettuce as phytoremediation of chlorine in water; to determine the ability of those plants, as well as to accumulate and translocate chlorine in water, bioconcentration factor $(B C F)$, and translocation factor (TF). The research method was used, namely the experimental design method to find the effect of certain treatments on controlled conditions. The results of the study concluded that water hyacinth (Eicchorniacrassipes (Mart.) Solms), heart shape false pickerelweed (Monochoria vaginalis (Burm.F) Presi), and water lettuce (Pistia stratiotes L.) have the ability as phytoremediating agents for chlorine in water, with absorption respectively $79.58 \%$ for water hyacinth, $73.60 \%$ heartshape false pickerelweed, and 87.39\% for water lettuce. These plantsare hyperaccumulators if the absorption / accumulation rate is at least 1000 ppm of contaminants. Thus, the three types of plants (Eichhorniacrassipes, Monochoria vaginalis, and Pistia stratiotes) can be categorized as hyperaccumulator plants for chlorine because their accumulation levels are respectively $1492.35 \mathrm{ppm}$ (E.crassipes), $1374 \mathrm{ppm}$ (M. vaginalis), and $1631.28 \mathrm{ppm}$ (P. stratiotes).

Keywords---chlorine, heart shape false pickerelweed, phytoremediation, water hyacinth, water lettuce.
\end{abstract}

\section{Introductions}

Water is one of the necessities in life and a basic element for all living things on earth. Over time and the progress of civilization, the need for water has increased because it needed by the population is not only for drinking but also for bathing, washing, industries, swimming, and other needs (Susanna, 2001). In connection with this, there are currently a lot of water sources that have been contaminated by microorganisms (bacteria), therefore purification is carried out to overcome this problem by using chlorine.

According to Meilasari (2012), chlorine is one of the elements that exist on earth and is rarely found in free form. In general, chlorine is found bonded with other elements or compounds. In human life, chlorine plays an important role in many things that we use every day such as paper, coolants, cleaning sprays, solvents, and various other products. Chlorine is a chemical that is commonly used as a germ killer. It will react with air to form hypochlorous acid which is known to damage cells in the body. Chlorine in rice will erode the intestinal mucosa in the stomach (corocytes), making it susceptible to ulcer disease. In the long term, consuming rice containing chlorine will cause liver and kidney cancer (Wongkar, 2014). Besides having the impacts on health, chlorine also has it in the environment, whether in the water, in the air, and in the communities. The use of chlorine has long-term and shortterm effects. The magnitude of the impact caused by chlorine depends on the level, type of chlorine compound, and most importantly the level of the compound's toxicity. The effects of chlorine on health can interfere with the immune system, damage the liver and kidney, cause indigestion, nervous system disorders, cancer, and reproductive system disorders that can lead to miscarriage (Rahmi, 2016; Petrucci \& Rosellini, 2005; Avlonitis et al., 1992).

Phytoremediation is a technique for restoring polluted land by using plants to absorb, degrade, and transform pollutants, both heavy metals and organic compounds. This method is easy to apply, efficient, inexpensive, and environmentally friendly (Glass, 1999). At this time, many plants that are known to have the ability to remediate polluted environments include those that have the potential to become chlorine phytoremediators, namely water hyacinth, heart shape false pickerelweed, and water lettuce. Various previous studies have shown the benefits of 
water hyacinth, among others, Hartanti et al. (2014), concluded that phytoremediation using water hyacinth plant in leather tanning liquid waste can reduce the chromium metal content until it is following predetermined quality standards. It has also been found that water hyacinth is useful for removing inorganic nutrients, toxic metals, and persistent organic pollutants (Malik, 2007). Furthermore, Fariez et al. (2014), obtained data that the water hyacinth plant was able to absorb 2.18-10.98 ppm (41\% -59\% of initial concentration) ortho-chlorophenol pollutants with an effective contact time of 48 hours. Meanwhile, heart shape false pickerelweed also can act as a phytoremediation agent. This can be proven based on research by Fariez et al., (2014) which stated that heartshape false pickerelweed plant was able to absorb $22,289 \mathrm{mg} / \mathrm{kg}$ of arsenic in the root tissue and $2.5833 \mathrm{mg} / \mathrm{kg}$ in leaf tissue.

The results of the research of Fonkou et al. (2002), reported that water lettuce could reduce several water parameters such as turbidity, total iron, color, COD, BOD, TSS, and DO by more than 70\%. Also, Ervina et al. (2019), concluded that water lettuce was able to reduce temperature parameters by $16.9 \%$, sulfate by $43.1 \%$, and phosphate by $41.9 \%$.

\section{Materials and Method}

This research was conducted in the Greenhouse of the Faculty of Mathematics and Natural Sciences, Indonesian Christian University in Tomohon, while the sample analysis was carried out at the Laboratory of the Manado Industrial Research and Standardization Center, North Sulawesi. The research was conducted in June - July 2018. The research materials were water hyacinth, heart shape false pickerelweed, water lettuce, and chlorine compound $(\mathrm{CaOCl})$ which was obtained from chlorine/calcium hypochlorite powder. The tools used in this study were a bucket with a capacity of 10 liters, mortar, cool box, plastic paper, label paper, scale, digital camera, UV spectrophotometer.

The method used in this research was the laboratory experimental method. The experimental method is a research method that is used to find the effect of certain treatments on others under controlled conditions. According to Sugiyono (2008), laboratory experimental methods are used to collect data related to field experiments, which are then followed by laboratory analysis. This study used a two-way randomized block design / two-way RBD (group I consisted of 2427 ppm chlorine concentration (Block 1), group II 1781 ppm (Block 2), and group III 1372 ppm (Block 3) and the control group $0 \mathrm{ppm}$ ) with 3 treatments consisting of the plants, water hyacinth, heart shape false pickerelweed and water lettuce (Soda et al., 2007; Upadhyay \& Panda, 2009). According to Tapehe (2014), what is meant by randomized block design (RBD) is an experimental design that allows one-way error control. Sample and material preparation and sample testing were carried out at the Laboratory of the Manado Industrial Research and Standardization Center, North Sulawesi.

On the procedure and research implementation, the preparation stage began with collecting and listing tools and materials to be used. The water hyacinth was obtained from its population in Lake Tondano, water lettuce was taken from its population in Lake Sineleyan, while the heart shapes false pickerelweed was taken from its population in the vicinity of the community's rice fields in Lahendong village (Reddy et al., 1990; Kim \& Kim, 2000). The experimental plants were selected with the criteria of 2 months of age or before the generative period and there were no defects in the (healthy) parts of the plant, then acclimatized for one week in water media in an acclimatization tank. Acclimatization aims at physiological adjustments and adaptation of the new environment of experimental plants with experimental media. After the acclimatization period ended, samples of water hyacinth, heart shape false pickerelweed, and water lettuce to be used were selected that were healthy (no defects) and weighed 500 grams. The planting medium was prepared for testing in a plastic bucket that had been added with chlorine powder $(\mathrm{CaOCl} 2)$ with a concentration range of 2427 ppm (Block 1), 1781 ppm (Block 2), 1372 ppm (Block 3), and 0 ppm (control).

Experiments were carried out for 28 days, and sampling was carried out at 0 day, 7 days, 14 days, 21 days, and 28 days. Observation of plant morphology was carried out by observing and recording changes (leaves, stems, and roots) that may occur in response to the absorption of chlorine content in the growing medium. The intended morphological change is the possibility of chlorosis in plants, dwarfism, and others. The variables observed in this study were chlorine concentration in water samples and chlorine concentration in root and crown tissue. Samples of plant tissue (roots and crown) that have been prepared at the end of the observation were washed to remove the mud that sticks to the plant organs. After that, the sample was weighed 10 grams, then was mashed using a blender to make a wet extract, and continued with the analysis of the chlorine content in each plant tissue using the titration method.

Bioconcentration Analysis (BCF) and Translocation Factor (TF), according to Mangkoedihardjo (2007); Hariyadi (2014), the mechanism of accumulation of heavy metals including chlorine in plants can be calculated based on the bioconcentration factor and translocation factor with the following formula: 
a. Bioconcentration $(\mathrm{BCF})=\mathrm{Cs} / \mathrm{Ct}$

b. Translocation Factor $(\mathrm{TF})=\mathrm{Cx} / \mathrm{Cy}$

Information:

$\mathrm{Cs}=$ concentration of contaminants in plants

$\mathrm{Ct}=$ concentration of contaminants in the growing medium

$\mathrm{Cx}=$ concentration of contaminants in other parts of the plant (crown)

$\mathrm{Cy}=$ Concentration of contaminants in roots

The principle that needs to be considered is the BCF and TF factors as indicators that can distinguish the accumulation mechanism between phytostabilization and phytoextraction. If $\mathrm{BCF}>1$ and $\mathrm{TF}<1$, the mechanism is phytostabilization. In contrast, if $\mathrm{BCF}<1, \mathrm{TF}>1$, the mechanism is phytoextraction (Yoon et al., 2006).

\section{Result and Discussions}

The results of the analysis of chlorine concentration in water samples and tissue samples before treatment (0 days) based on laboratory tests obtained results for chlorine concentrations, namely $2427 \mathrm{ppm}$ (Block 1), 1781 ppm (Block 2), and $1372 \mathrm{ppm}$ (Block 3), while for controlled block contained natural chlorine at $487.8 \mathrm{ppm}$. Meanwhile, the chlorine content in plant tissue samples is listed in Table 1.

Table 1

Chlorine levels in plant tissues before treatment ( 0 days)

\begin{tabular}{clcc}
\hline \multirow{2}{*}{ No. } & \multicolumn{1}{c}{ Plants } & \multicolumn{2}{c}{ Tissue (ppm) } \\
\cline { 3 - 4 } & \multicolumn{1}{c}{ Root } & Crown \\
\hline 1. & Water hyacinth & 328.9 & 748.7 \\
2. & Heartshapefalse pickerelweed & 283.2 & 589.9 \\
3. & Water lettuce & 317.6 & 794.1 \\
\hline
\end{tabular}

The chlorine content contained in the controlled samples came from natural chlorine in groundwater and from the pipes used to drain the water. Meanwhile, the habitat of the three plants also affects the concentration of chlorine in plant tissue because the three plants live around the rice fields and in the lake area which is sufficient to contribute to the presence of chlorine through various activities carried out to the resulting waste. Apart from that, chlorine is also a nutrient needed by plants so that it allows the chlorine in the plant organ as stated by Daru (2009), that chlorine is a micronutrient that plants need. The description of the absorption and accumulation rate of chlorine from three types of plants during the study can be seen in Table 2 .

Table 2

Results of analysis of chlorine concentration in water during the study

\begin{tabular}{lccccccccc}
\hline \multirow{2}{*}{$\begin{array}{c}\text { Contact } \\
\text { Time }\end{array}$} & \multicolumn{3}{c}{ Water Hyacinth } & \multicolumn{3}{c}{$\begin{array}{c}\text { Plants } \\
\text { Heart shape False } \\
\text { Pickerelweed }\end{array}$} \\
\cline { 2 - 12 } \multicolumn{1}{c}{ Day) } & 2427 & 1781 & 1372 & 2427 & 1781 & 1372 & 2427 & 1781 & 1372 \\
& $\mathrm{ppm}$ & $\mathrm{ppm}$ & $\mathrm{ppm}$ & $\mathrm{ppm}$ & $\mathrm{ppm}$ & $\mathrm{ppm}$ & $\mathrm{ppm}$ & $\mathrm{ppm}$ & $\mathrm{ppm}$ \\
\hline 7 days & 510.4 & 816.7 & 476.4 & 884.8 & 1497.4 & 453.8 & 328.9 & 283.6 & 249.6 \\
14 days & 419.7 & 340.3 & 328.9 & 510.5 & 431.9 & 272.6 & 283.6 & 260.9 & 204.1 \\
21 days & 294.9 & 294.3 & 226.8 & 431.1 & 397.1 & 249.6 & 249.1 & 192.8 & 181.5 \\
28 days & 272.3 & 283.6 & 147.5 & 192.8 & 317.6 & 192.8 & 204.1 & 158.9 & 147.5 \\
\hline
\end{tabular}

Based on the results of the statistical analysis contained in Table 3, it can be explained that "plant type" and "observation time" have a significant effect on the percentage value of chlorine absorption during study time. This can be proven by the significant values possessed by both of them, namely, 0.006 for "plant type" and 0,000 for "time of observation", meaning that "plant type" and "observation time" give influence. 
Table 3

Results of statistical analysis of chlorine absorption percentage

\begin{tabular}{lrrrrc}
\hline Source of Diversity & \multicolumn{1}{c}{ JK } & \multicolumn{1}{c}{ db } & \multicolumn{1}{c}{ KT } & \multicolumn{1}{c}{ F } & \multicolumn{1}{c}{ Sig. } \\
\hline Corrected Model & $4532,00^{\mathrm{a}}$ & 11 & 412,00 & 4,57 &, 001 \\
Intercept & 231490,89 & 1 & 231490,89 & 2570,26 &, 000 \\
Plant Type & 1148,82 & 2 & 574,41 & 6,38 &, 006 \\
Observation Time & 2506,20 & 3 & 835,43 & 9,28 &, 000 \\
Block & 491,94 & 2 & 245,97 & 2,73 &, 085 \\
Plant Type* Block & 384,94 & 4 & 96,23 & 1,07 &, 394 \\
Error/Residue & 2161,56 & 24 & 90,06 & & \\
Total & 238184,45 & 36 & & & \\
\hline Corrected Total & 6693,57 & 35 & & & \\
\hline
\end{tabular}

Table 3 showed the results of further tests (Duncan) for "plant type" which are known to have a significant effect on the percentage value of chlorine absorption. According to the test results, it can be seen that the percentage value of absorption of three types of plants is in the same subsets column or different subsets columns. For water hyacinth plants in the subsets column 1 and subsets column 2 , it can be explained that the water hyacinth plant does not have a significant difference to heart shape false pickerelweed and water lettuce plants. In contrast to the case of water hyacinth and water lettuce, which are in the two different subsets columns (water hyacinth subsets column 1 and water lettuce subsets 2). This indicates that these two plants have a significant difference in the value of the percentage level of chlorine absorption.

Table 4

Percentage of chlorine absorption rate of three types of plants during the research

\begin{tabular}{cccc}
\hline \multirow{2}{*}{ Plant types } & $\mathrm{N}$ & \multicolumn{2}{c}{ Subsets } \\
\cline { 3 - 4 } & & $73,60 \%$ & 2 \\
\hline M. vaginalis & 12 & $79,58 \%$ & $79,58 \%$ \\
E. crassipes & 12 & & $87,39 \%$ \\
P. Stratiotes & 12 & & \\
\hline
\end{tabular}

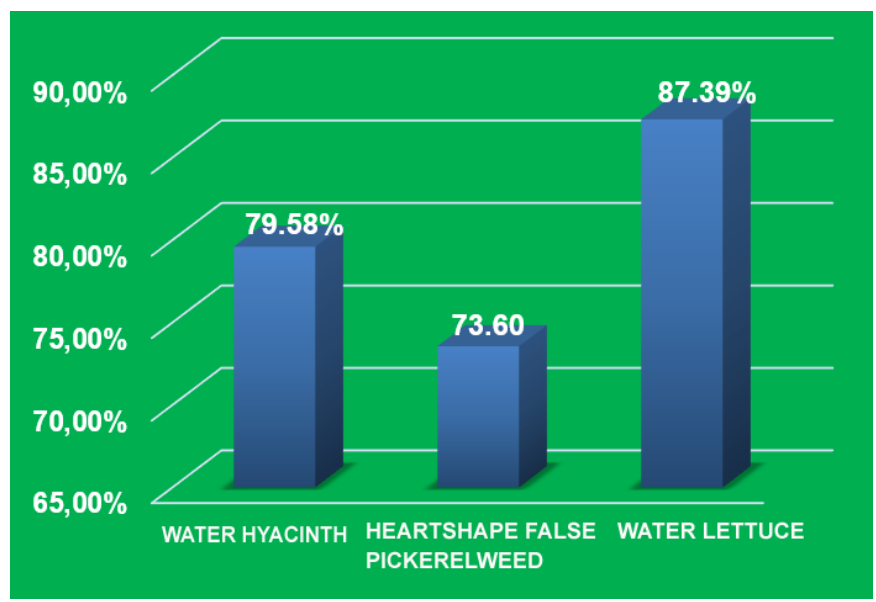

Figure 1. Percentage of Chlorine Absorption Rate of the Three Types of Plants during the Research

Meanwhile, according to the results of statistical analysis which was then correlated with the results of the research that had been done, it showed that the three plants can absorb and accumulate chlorine into their tissue. Table 3 (further test results / Duncan) and Figure 1 showed the value of the absorption rate during the study time (28 days) for each plant is different, this can happen because each plant has a different adaptation process and tolerance to the surrounding environment. 
The water lettuce plant showed the highest absorption rate of the three types of plants with an average percentage value of $87.39 \%$ with an absorption value of $1631.28 \mathrm{ppm}$. Meanwhile, the water hyacinth plant had an average absorption percentage value of $79.58 \%$ with an absorption value of $1492.35 \mathrm{ppm}$. Meanwhile, the heart shape false pickerelweed plant had an average absorption percentage value of $73.60 \%$ with an absorption value of $1374.00 \mathrm{ppm}$.

In this study, the average number of clumps for water hyacinth and heart shape false pickerelweed plants was between 5-6 clumps. Meanwhile, the water lettuce plant had an average clump of 10-11. Based on this, it can be proven that the absorption of the water lettuce plant to chlorine is higher when it is compared to the other two plants.

Apart from the number of clumps, the level of effectiveness of a plant in absorbing pollutants (chlorine) can be identified from the root fibers owned by the plant. Aquatic plants that float on the surface of the water have thick fibrous roots. Fibrous roots have much root hair approximately the same size and emerge from the base of the root and spread sideways and in all directions. The fibrous roots form branches with not too different in sizes. The two types of plants (water hyacinth and heart shape false pickerelweed) that were used are known to have a fairly good root system so that they can absorb chlorine. Also, the ability and effectiveness of the three types of plants in the chlorine absorption process are supported by the habitats of these three plant types that live in rice fields and lakes where have extreme environments with various kinds of pollution elements.

\section{Chlorine absorption based on contact time (observation)}

According to the results listed in the following tables and figures, it can be explained that the longer the contact time, the lower the chlorine concentration in the respective media. This indicates that the absorption and accumulation processes are carried out by each plant.

Based on the results of observations made on three types of plants, it can be concluded that the absorption process of chlorine concentration in each treatment is only significant over 7 days. This can happen because after 7 days the plant begins to experience damage to several organs, especially the leaves (chlorosis) so that it can automatically affect the physiological and metabolic processes of the plant itself in absorbing pollutants in the media (chlorine).

This result can be proven based on the results of the statistical analysis listed in the previous Table 3 which explains that the "time of observation/contact" also has a significant effect on the rate of absorption/reduction of chlorine concentration in water media. Continued from Table 3 for the significant value of the contact/observation time variable then a further test was made as in the following table:

Table 5

Chlorine content based on contact time

\begin{tabular}{lccc}
\hline \multirow{2}{*}{ Observation Time } & \multirow{2}{*}{ N } & \multicolumn{2}{c}{ Subsets } \\
\cline { 3 - 4 } Day 7 & 9 & 1 & 2 \\
Day 14 & 9 & $339,17 \mathrm{ppm}$ & \\
Day 21 & 9 & $279,69 \mathrm{ppm}$ & \\
Day28 & 9 & $213,01 \mathrm{ppm}$ & \\
\hline
\end{tabular}

According to the results in Table 5, it can be explained that at the time of contact/observation on the 7th day, the remaining chlorine in the water medium was $611.29 \mathrm{ppm}$. This means that the average of the three types of plants has a significant ability to absorb chlorine within 7 days.

\section{Absorption results in plant tissues after the end of the research}

The results of research on chlorine absorption in root and crown tissue at the time of treatment showed that three types of plants; Water hyacinth, heart shape false pickerelweed, and water lettuce can adapt and tolerate absorption of chlorine during treatment, containing varying chlorine in the root and crown tissue. This shows that the three types of plants have the potential to absorb significant chlorine, as a phytoremediator agent for treating polluted water environments, to exploit the potential of natural resources and biodiversity.

Based on the results of the analysis of chlorine content in plant tissue (Table 9), it can be explained that the average value possessed by each plant type in each treatment shows that the highest level of chlorine accumulation in the three types of plants is found in the crown section. This result is different from the research conducted by Zumani et al. (2015), which states that the highest level of accumulation occurs in plant roots. 
Table 6

Chlorine content in root and crown tissue

\begin{tabular}{|c|c|c|c|c|c|c|c|c|}
\hline \multirow{3}{*}{$\begin{array}{l}\text { Plants } \\
\text { (Treatment) }\end{array}$} & \multicolumn{8}{|c|}{ Block/Group } \\
\hline & \multicolumn{2}{|c|}{ Control } & \multicolumn{2}{|c|}{$2427 \mathrm{ppm}(\mathrm{B} 1)$} & \multicolumn{2}{|c|}{$1781 \mathrm{ppm}(\mathrm{B} 2)$} & \multicolumn{2}{|c|}{1372 ppm (B3) } \\
\hline & Root & Crown & Root & Crown & Root & Crown & Root & Crown \\
\hline Water Hyacinth & 328.9 & 748.7 & 295.4 & 964.2 & 283.6 & 907.5 & 260.9 & 850.8 \\
\hline Heart shape False & & & & & & & & \\
\hline Pickerelweed & 283.2 & 589.9 & 272.3 & 805.4 & 249.6 & 794.1 & 215.5 & 669.3 \\
\hline Water Lettuce & 317.6 & 794.1 & 794.1 & 862.1 & 555.9 & 986.9 & 431.1 & 1123.1 \\
\hline Average & 309.9 & 710.9 & 453.9 & 877.2 & 363.0 & 896.1 & 302.5 & 881.0 \\
\hline
\end{tabular}

The difference in the level of accumulation that occurs in the root and crown tissue parts can occur because chlorine is a micronutrient that plays a role in the physiological process of plants, one of which is involved in the photosynthesis process, so it has a high probability of being distributed to the plant crown. Apart from these causes, it can also be explained that the nature of the contaminants and the form of adaptation of plants to contaminant concentrations also affect differences in the level of chlorine accumulation.

\section{Bioconcentration Factor (BCF) and Translocation Factor (TF)}

To determine the ability of three types of plants (water hyacinth, heart shape false pickerelweed hyacinth, and water lettuce), to accumulate and translocate chlorine, it is necessary to calculate the bioconcentration factor (BCF) and the translocation factor (TF). The bioconcentration factor is defined as the ratio between the chlorine concentration in plants and the chlorine concentration in water media. The ability of plants to transfer chlorine from the roots to the top of the plant is referred to as a translocation factor which is defined as the ratio of the metal concentration present in the leaves to the plant roots.

The results of the calculation showed that the TF value is higher while the BCF value is lower as listed in Table 10 and Figure 11. The results indicated that the three plant types have the greatest ability to translocate chlorine to other parts of plant organs (crown). High TF and low BCF indicated that the phytoremediation mechanism that occurs in these three plant species is phytoextraction. The phytoextraction process is where the plant can translate contaminants from the roots to the plant crown.

Table 10

Calculation results of $\mathrm{BCF}$ and $\mathrm{TF}$ value

\begin{tabular}{lll}
\hline Plants & BCF & TF \\
\hline Water Hyacinth & 0,66 & 3,24 \\
Heartshape False Pickerelweed & 0,55 & 3,08 \\
Water Lettuce & 0,89 & 2,15 \\
\hline
\end{tabular}

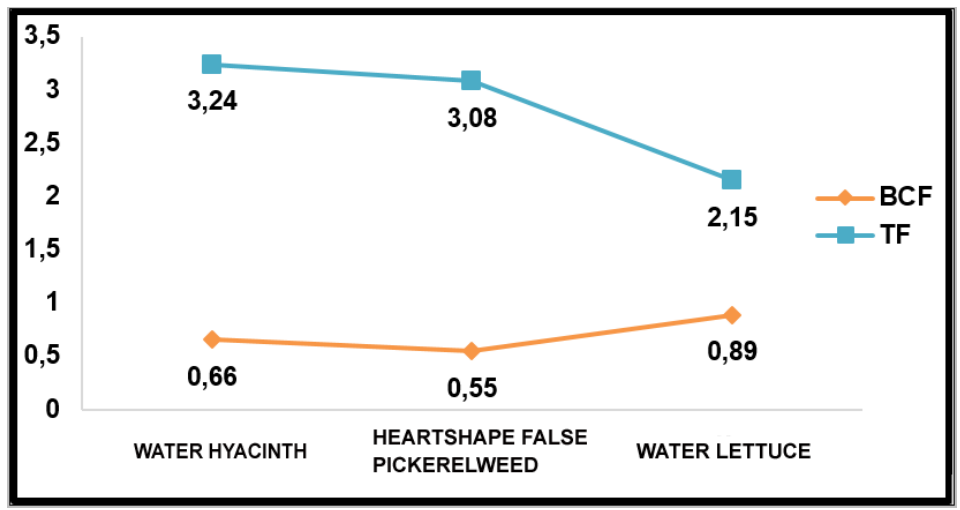

Figure 2. Value of BCF and TF in three types of plants 
A plant can be called a hyperaccumulator if the absorption/accumulation rate is a minimum of $1000 \mathrm{ppm}$ of contaminants. Thus, based on the results of research that has been carried out, three types of plants (Eichhorniacrassipes, Monochoria vaginalis, and Pistia stratiotes) can be categorized as hyperaccumulator plants for chlorine because their accumulation levels are $1492.35 \mathrm{ppm}$ (E.crassipes), $1374 \mathrm{ppm}$ respectively. (M. vaginalis), and $1631.28 \mathrm{ppm}$ (P. stratiotes).

The BCF and TF factors are indicators that can distinguish the accumulation mechanism between phytostabilization and phytoextraction. If the value of $\mathrm{BCF}>1$ and $\mathrm{TF}<1$, the mechanism is phytostabilization. In contrast, if the value of $\mathrm{BCF}<1$ and $\mathrm{TF}>1$, the mechanism is phytoextraction. In this study, $\mathrm{BCF}<1$ and $\mathrm{TF}>1$ indicated the phytoextraction mechanism. The TF value which is inversely proportional to the BCF value shows that the three types of plants have a high ability to translocate chlorine to other parts of plant organs.

\section{Conclusion}

Based on the results of the research that has been done, it can be concluded that the plants of water hyacinth (Eicchorniacrassipes (Mart.) Solms), heart shape false pickerelweed (Monochoria vaginalis (Burm.F) Presi), and water lettuce (Pistia stratiotes L.) have the ability as agents of phytoremediation of chlorine in water, with successive absorption rates of $79.58 \%$ for water hyacinth, $73.60 \%$ for water hyacinth, and $87.39 \%$ for water lettuce.

A plant can be called a hyperaccumulator if the absorption/accumulation rate is a minimum of $1000 \mathrm{ppm}$ of contaminants. Thus, based on the results of research that has been carried out, the three types of plants (Eichhorniacrassipes, Monochoria vaginalis, and Pistia stratiotes) can be categorized as hyperaccumulator plants for chlorine because their accumulation levels are $1492.35 \mathrm{ppm}$ (E.crassipes), $1374 \mathrm{ppm}$ respectively. (M. vaginalis), and $1631.28 \mathrm{ppm}$ (P. stratiotes).

\section{Acknowledgments}

Special thanks to the Minister of National Education of the Republic of Indonesia, the Chancellor of the UKI Tomohon, the Dean of FMIPA UKI Tomohon, and the Head of Biology Department, FMIPA UKI Tomohon, who allowed writing this journal.

\section{References}

Avlonitis, S., Hanbury, W. T., \& Hodgkiess, T. (1992). Chlorine degradation of aromatic polyamides. Desalination, 85(3), 321-334. https://doi.org/10.1016/0011-9164(92)80014-Z

Daru, P., A. (2009). Health. URL http://neffo-lovers.blogspot.com/2009/03/pengujian-kadar-khlorida-metode.html

Ervina, M., Lie, H. S., Diva, J., Tewfik, S., \& Tewfik, I. (2019). Optimization of water extract of Cinnamomum burmannii bark to ascertain its in vitro antidiabetic and antioxidant activities. Biocatalysis and Agricultural Biotechnology, 19, 101152. https://doi.org/10.1016/j.bcab.2019.101152

Fariez, F., Chairul, C., Said, S., \& ZA, Z. (2014). Fitoremediasi Air Tercemar Polutan Amoniak dengan Memanfaatkan Eceng Gondok (Eichornia Crassipes) (Doctoral dissertation, Riau University).

Fonkou, T., Agendia, P., Kengne, I., Akoa, A., \& Nya, J. (2002, January). Potentials of water lettuce (Pistia stratiotes) in domestic sewage treatment with macrophytic lagoon systems in Cameroon. In Proceedings of International Symposium on Environmental Pollution Control and Waste management," EPCOWM'2002 (pp. 709-714).

Glass, D. J. (1999). Current market trends in phytoremediation. international Journal of Phytoremediation, 1(1), 1-8.

Hariyadi. (2014). Fitoremediasi Arsen Pada Air Limbah Panas Bumi PGE Lahendong dengan Eceng padi (Monocaria vaginalis), Kiambang (Salviniamolesta), dan Keladi Air (Colacasiaesculanta (Disertasi tidak diterbitkan). Universitas Brawijaya Malang, Malang.

Hartanti, P. I., Haji, A. T. S., \& Wirosoedarmo, R. (2014). Pengaruh kerapatan tanaman eceng gondok (Eichornia crassipes) terhadap penurunan logam chromium pada limbah cair penyamakan kulit. Jurnal Sumberdaya Alam dan Lingkungan, 1(2), 31-37.

Kim, Y., \& Kim, W. J. (2000). Roles of water hyacinths and their roots for reducing algal concentration in the effluent from waste stabilization ponds. Water Research,34(13), 3285-3294. https://doi.org/10.1016/S00431354(00)00068-3

Malik, A. (2007). Environmental challenge vis a vis opportunity: the case of water hyacinth. Environment international, 33(1), 122-138. https://doi.org/10.1016/j.envint.2006.08.004 
Mangkoedihardjo, S. (2007). Phytotechnology integrity in environmental sanitation for sustainable development. Journal of Applied Sciences Research, 3(10), 1037-1044.

Meilasari, F. (2012). Klorin. fitrianameilasari. URL https://fitrianameilasari.wordpress.com/2012/05/04/klorin/

Petrucci, G., \& Rosellini, M. (2005). Chlorine dioxide in seawater for fouling control and post-disinfection in potable waterworks. Desalination, 182(1-3), 283-291. https://doi.org/10.1016/j.desal.2005.02.029

Rahmi, S. (2016). Identifikasi Kualitatifklorin Pada Beras Yang Diperjualbelikan Di Pasar. Jurnal Penelitian Pendidikan Mipa, 1(2), 72-77.

Reddy, K. R., Agami, M., \& Tucker, J. C. (1990). Influence of phosphorus on growth and nutrient storage by water hyacinth (Eichhornia crassipes (Mart.) Solms) plants. Aquatic botany, 37(4), 355-365. https://doi.org/10.1016/0304-3770(90)90021-C

Soda, S., Ike, M., Ogasawara, Y., Yoshinaka, M., Mishima, D., \& Fujita, M. (2007). Effects of light intensity and water temperature on oxygen release from roots into water lettuce rhizosphere. Water research, 41(2), 487-491. https://doi.org/10.1016/j.watres.2006.10.009

Sugiyono. (2008). Metode penelitian pendidikan:(pendekatan kuantitatif, kualitatif dan $R \&$ \&). Alfabeta.

Susanna, D. (2001). Kesehatan Lingkungan. Universitas Indonesia, Jakarta.

Tapehe, Y. (2014). Statistika dan Rancangan Percobaan. Jakarta: EGC.

Upadhyay, R. K., \& Panda, S. K. (2009). Copper-induced growth inhibition, oxidative stress and ultrastructural alterations in freshly grown water lettuce (Pistia stratiotes L.). Comptes rendus biologies, 332(7), 623-632. https://doi.org/10.1016/j.crvi.2009.03.001

Wongkar, I. Y. (2014). Analisis Klorin pada Beras yang Beredar di Pasar Kota Manado. PHARMACON, 3(3).

Yoon, J., Cao, X., Zhou, Q., \& Ma, L. Q. (2006). Accumulation of $\mathrm{Pb}, \mathrm{Cu}$, and $\mathrm{Zn}$ in native plants growing on a contaminated Florida site. Science of the total environment, 368(2-3), 456-464. https://doi.org/10.1016/j.scitotenv.2006.01.016

Zumani, D., Suryaman, M., \& Dewi, S. M. (2015). Pemanfaatan Eceng Gondok (Eichhornia crassipes (Mart.) Solms) untuk Fitoremediasi Kadmium (Cd) pada Air Tercemar. Jurnal Siliwangi Seri Sains dan Teknologi, 1(1). 